\title{
WHAT IS COMMUNICABLE? Unaccounted Injuries and "Catching" Diabetes in an Illegible Epidemic
}

\author{
AMY MORAN-THOMAS \\ Massachusetts Institute of Technology \\ (iD) https:/ / orcid.org/0000-0001-5411-1046
}

By the time we met in southern Belize, Dr. W had already named it in his mind: the "Caribbean diabetic limb crisis." He said that he hoped someone would conduct a study about the trauma caused by diabetic amputations, and not just for patients. He felt someone should also do a study about the trauma for surgeons put in the position of repeatedly removing pieces of their patients.

It took me a moment to put together the fact that Dr. W was one of those surgeons.

"You can't imagine how much I never want to see another person lose their foot," he would tell me later. "But I know that each day I do this, that's what's coming."

Archaeologists say the world's oldest known prosthetic appendages are mostly toes, fashioned nearly 3,000 years ago in Egypt out of wood, leather, linenlike plant fibers, and glue (Nerlich et al. 2000). In 2010, I never met anyone who bothered with prostheses for "just a toe." But if you looked at the sandals of the people gathering in lines in Dangriga that morning, you could see that a number were missing digits. Those waiting to see the doctors appeared to come from all walks of life: I observed stylish fashions and threadbare clothing, people formidable in stature and others looking markedly thin, a mix of skeptical-looking teen- 


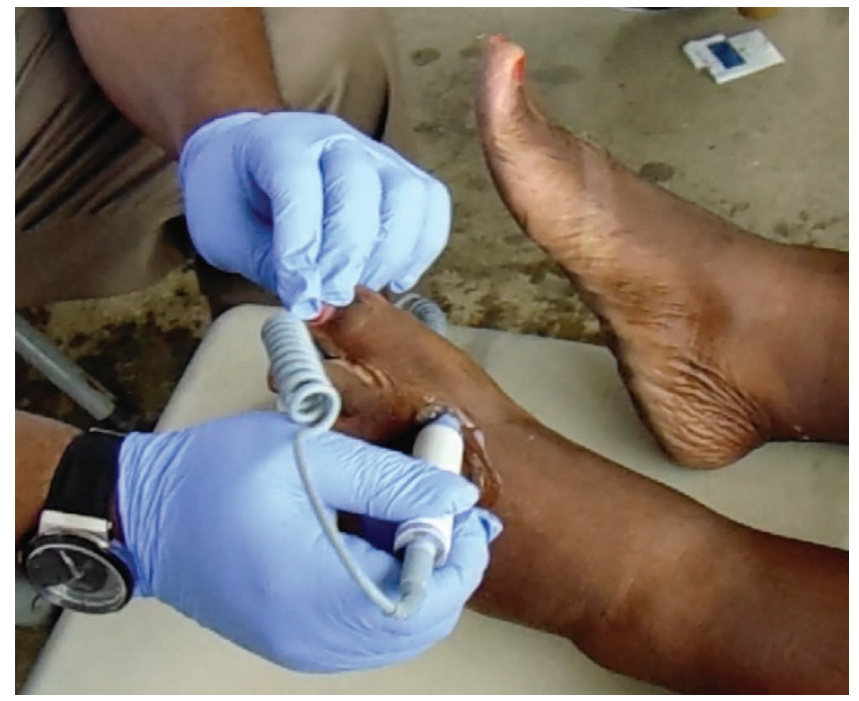

Figure 1. Dr. W at work in Dangriga. Photo by Amy Moran-Thomas.

agers and grandmothers in weathered hats. The members of the Belize Diabetes Association (BDA)'s many branches and their colleagues from the Belize Ministry of Health arriving in the southern town of Dangriga unpacked supplies for the day, arranging stations around an open public pavilion. The team's mood was relaxed and convivial. Only their gear, plastic boxes packed with foot care instruments, hinted at the day's high stakes.

Dr. W's team brought a stack of photocopied papers, titled "LIMB SALVAGE FORM." These sheets displayed sketched outlines of feet: a right and left foot shown from both bottom and top views, with circles outlining the twenty-two quarter-sized places where podiatrists test for sensation to detect any signs of lost feeling. "Can the patient see the bottom of their feet?" the paper asked, just above a question about the safety of shoes.

The Belize Diabetes Association of New York collaborates with Dr. W's Diabetic Foot Center Group team, which since 2004 has been traveling between their New York City base and a range of Caribbean countries. Their group focused on foot maintenance checkups, only one station among an array of services offered around the pavilion. When requested, they provide training to build expertise and capacities among local caregivers. On occasion, Dr. W also performs follow-up salvage surgeries to restore a diabetic limb that may have already been scheduled for amputation. In medicine, the term salvage means that all possible measures are taken to ensure an ailing limb stays alive and attached. Limb salvage procedures often include vascular surgery measures to restore blood flow, such as unblocking 
blood vessels or placing stents. They most broadly demand the careful monitoring of feet to catch and treat tiny wounds before they reach a crisis point.

This labor has its own lexicon. I made lists of unfamiliar terms in my notebook.

Claudication comes from a Latin verb meaning "to limp," the name for stabbing leg pains caused by restricted blood flow. It is often linked to peripheral artery disease, which most doctors just call PAD. Debriding means removing dead tissue to try to give the living tissue around it a chance to heal. The paperwork's "Deformities" box holds checklists of things you did not know could go wrong with parts of your feet you did not know existed: A "dorsiflexed first ray" means that the foot segment containing the first cuneiform and first metatarsal bones rides high; there are two other check boxes nearby on the page to indicate a concerning equinus (plantar flex forefoot) or depressed calcaneus (heel bone). (The feet's cuneiform bones are wedge-shaped, recalling the ancient Mesopotamian pictographic script once etched on clay tablets with wedge-shaped implements.)

The physicians paid close attention to each detail, trying to tune out the long lines of people waiting around them. Any concerning characteristic on a diabetic foot could morph into catastrophic injury if it went unnoticed and untended for a few weeks: maceration or tinea between the toes, obstructed dorsalis pedis or posterior tibial pulses, ankle plantar flexion, bunions, drop foot, Charcot fracture. And a very serious acronym: LOPS, loss of protective sensation. Dr. W's team had set up a station teaching people strategies like using their hands to feel inside their shoes before putting them on, since feet numbed by diabetes can be felled even by tiny injuries. The need for amputation can often be traced back to a stone in someone's shoe or a bug bite on an ankle. One U.S. study about the causes of diabetic limb amputation found at least twenty-three unique causal pathways in play (including ischemia, infection, neuropathy, faulty wound healing, gangrene, and initial minor trauma). Most amputations are caused by several mechanisms simultaneously — which is also why remediating any one pathway will not necessarily save a limb. The biggest pattern suggested that up to 80 percent of amputations were preceded by a "pivotal event," usually a minor cutaneous injury (Pecoraro, Reiber, and Burgess 1990). In Dee's case, the pivotal event that led to her losing her leg was stepping on a seashell one morning.

Such amputations and injuries are rising worldwide in lockstep with diabetes, which the International Diabetes Federation now estimates kills more people than AIDS and breast cancer combined (IDF 2017). Type 1 diabetes (about 5 percent of the world's cases) used to be commonly referred to as "juvenile diabetes," 
while more gradually developing type 2 used to be labeled "adult onset diabetes" (about 95 percent of diabetes cases). But today, more children are developing type 2 , and more adults type 1 . In untreated versions of either type, high or low blood sugar wears on the blood vessels carrying it, which over time can contribute to both macrovascular and microvascular injuries - such as wounds on limbs that might stop healing, blindness, and other organ failure. Many people I met in Belize's predominantly Garifuna Stann Creek District (see Palacio 2005)—where at least one in four adults and one in three women were living with type 2 diabetes alone by the time I began interviewing people in 2008 (Gough et al. 2008) — simply called all varieties of diabetes and its complications sugar.

That day, it turned out that several of the team's visiting doctors originally hailed from other parts of the Caribbean — part of the larger Caribbean Diabetes Initiative - and had connected in New York City with the Belizean group. People from Dangriga kept telling the team that the letters on their T-shirts, BDANY (an acronym for Belize Diabetes Association of New York) resembled a Garifuna word meaning "your time" — and by way of the little joke, let the BDANY members know they were grateful for their time.

"You have salt or sugar?" old friends called out to each other across the open pavilion.

(Both proved the most common answer - meaning diabetes along with hypertension.)

"I never thought you were sweet!"

No matter how many times we heard some version of the joke, everybody laughed.

\section{"CATCHING IT"}

As rising diabetes settled into social fabrics in Belize, rumors kept popping up that certain forms could be contagious. Diabetic sugar's terms traveled across languages: súgara in Garifuna, shuga in Belizean Kriol, azúcar in Spanish, kiha kiik in Kekchi, or ch'uhuk k'iik (sweet blood) in Mopan and Yucatec Mayan. ${ }^{1}$ I heard numerous stories about husbands and wives becoming afraid to sleep in the same room, with amputated limbs mentioned as the defining feature of these anxieties. "Well, here it comes for me," Laura recalled thinking when she was diagnosed with diabetic sugar in her twenties. "I knew it was coming for me, because my mom had it, my sister . . . we all have it.” The personified pathogens that people kept using to allude to their diabetic injuries came from the language of infection: many said of diabetes sugar that they "caught it." More ominously, others said of 
sugar "it caught me." These terms were based on people's firsthand observations of patterns, their mental maps of neighborhoods and families. The deeper puzzle, I began to think, was not why a fast-spreading fatal disease might be perceived as infectious, but rather how our terms for framing and addressing public health conditions came to be so dualistic in the first place.

The old paradigm of environmental miasma located disease agents in contaminated atmospheres and places, repurposing an ancient Greek word for ritual pollution. In the late nineteenth century, germ theory began to replace miasma paradigms with a strict dichotomy. Dominant models today still describe two basic ways to think about diseases: they are either "communicable" or "noncommunicable." In this binary schema, infectious diseases need to be addressed in terms of interrupting contagion between people, vectors, and environments via targeting exposures to disease-specific germs or biological pathogens (Porter 1999; Krieger 2011, 100). Meanwhile, since non-communicable diseases are by definition non-transmissible, they are commonly analyzed in biomedicine as a risk linked to an individual's inborn genetic constitution (Paradies, Montoya, and Fullerton 2007; Montoya 2011) or framed as resulting from personal choices and so-called lifestyle behaviors (see critiques in Yates-Doerr 2015; Hatch 2016; Mendenhall 2019).

In historical genealogies, the infectious/non-communicable dualism stands as a relatively recent invention. I wondered what these binary models of causation tend to foreclose or disable, seeing the disjuncture between diabetic injuries and how they are cast in common public health models. Communicability is not just a matter of seeing and interpreting the causes of disease, but also a factor shaping the plausibility and workability of treatment.

This essay offers a series of grounded scenes to think with the quandaries increasingly faced by caregivers and families around such overlooked aspects of diabetes complications. It explores the working idea of para-communicable conditions to reflect on the implications of contemporary models of communicability and causality raised by diabetes' patterned injuries. Seen through practices that make another model of problem and response visible, the work people are facing on the ground shows the material effects of infectious/non-communicable dualisms: how data get lost when we assume in advance that we know what a condition's markers look like, and how those distortions impact real access to available infrastructures of care.

Viewed in this way, each end-of-the-line injury like a diabetes-linked amputation could be read as what Marcel Mauss (1966, 76-78) called a "total social 
fact" — at once political, legal, economic, institutional, ecological, alimental, spiritual, and social (cf. Jain 2013). A total social fact demands a total social response. Yet only 2 percent of global health funding currently goes to all chronic conditions combined - leaving people around the world to negotiate the serious gaps between how these problems' causalities and urgencies get cast in the paperwork of public health models versus how they are actually manifesting in bodies.

\section{FOOT SOLDIERS}

"She's one of our best foot soldiers," Dr. W smiled as he and Nurse Elizabeth hugged hello. Years ago, he had arranged for her to complete diabetes foot care training. In the months or years between visits from the BDA's New York team, Elizabeth stood as the front line of defense for those in town who needed diabetic limb care.

Elizabeth's brother says she has nine lives, like a cat. As a steadfast nurse and head of the local Belize Diabetes Association branch, she had managed to maintain herself with type 1 diabetes through many decades and helped keep many others intact. She was trying hard to train others, since no one in this southern district of Belize — which also had no endocrinologist or podiatrist — had received specialty training in diabetes foot care. Elizabeth's special expertise included tending to diabetic toenails, a crucial skill: one clip at the wrong angle could lead to an ingrown nail and later infection, so trimming required complete attention.

The blue plastic tub labeled FOOT CARE quickly piled high with sterile medical wrappers and used gloves. Carefully emptied, it soon filled again. When a tall woman revealed four self-bandaged ulcers across both feet, Dr. W stood nearby as a collaborating physician tended to her. I knew the woman, Grace; she was part of a group that had convened when I once helped to coordinate a public forum on diabetes in Dangriga. I watched as the visiting doctor brushed sand from Grace's toes. She used a duplex Doppler ultrasound device to listen to Grace's feet for calcium blocks and other subtle acoustic clues, pressing on various points with a wand that amplified the sounds of blood flowing through the arteries.

Grace was already missing one of her big toes. Crumbled scar tissue and a protruding bone suggested that the digit had broken off with dry gangrene, rather than through a surgical cut. Making jokes about pedicures, the doctor took the foot firmly in her hand and asked Grace to close her eyes. The physician used an array of soft-point brushes and metal hammers to detect where and how Grace's nerves had numbed or deadened. Then she rubbed Grace's feet vigorously with soap until enough dead skin had sloughed away that the ulcers began to bleed at 
the edges — which might make regeneration possible. The newest ulcers formed perfectly round circles: bright raw pink and eerily symmetrical. But the doctors expressed more concern about how Grace's feet sounded: they could barely hear a pulse near her missing toe, signaling diminished blood flow in the tissue, which would make it much harder to heal.

Dr. W wished aloud to the team that there was some way they could give Grace two days in their New York hospital's hyperbaric chamber, the enclosed apparatus that can help otherwise impossible wounds begin to heal. "Is there any way you can get to New York, dear?" His invitation hovered in the air for a moment. But that afternoon, nobody knew any way to access a hyperbaric chamber. After Grace's remaining nine toes were wrapped in fresh bandages, her flip-flops would not fit back on over the dressed wounds. The doctors could only laugh in admiration at her raw tenacity when they saw her later climbing onto a bicycle. They knew the big toe is particularly crucial for balance, yet Grace moved with steady poise. Someone snapped a photo of her posing with gauze-wrapped feet pressed to the pedals, but their smiles looked privately worried. There was nothing left to do for the moment. We all watched as she rode away.

With an intensely focused look, Elizabeth pulled another foot onto her lap.

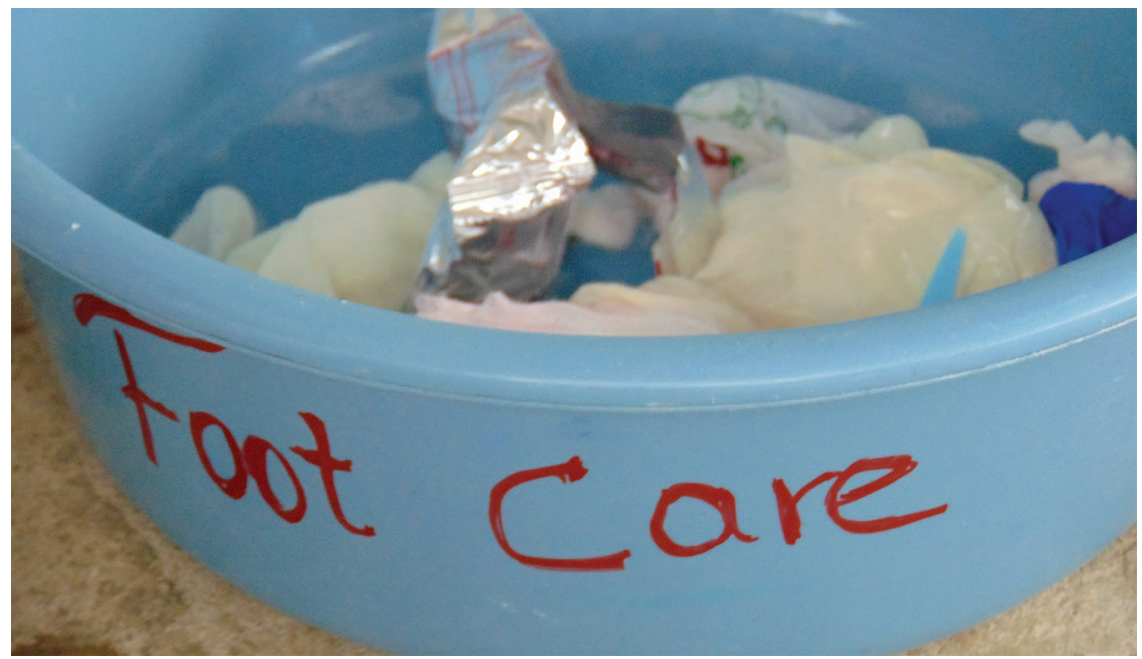

Figure 2. Diabetic foot care in practice. Photo by Amy Moran-Thomas.

As Laurence Ralph (2012) reflects about "living through injury," sometimes “it becomes politically strategic to inhabit the role of a 'defective body' in order to make claims" about the more subtle violence of an unjust system. Belize Diabetes Association groups face similar questions with immediate stakes: photos of hurt 
feet help them disrupt ideas of diabetes as a boring disease, and thus gain support to provide material care. For many members, this does not constitute an abstract or theoretical debate. It surfaces instead as a dilemma that unfolds in real timeas in the first week of 2018, when the BDA's Belmopan branch posted an arrangement of the new year's photos on their Facebook page.

The image was carefully composed to both shock and counter-anchor in a grounding context of caregiving and family dignity. The startling part featured pictures of four macerated feet in limbo with mottled wounds and missing toes. It had been posted by an energetic branch leader who also coordinates foot massages for preventing and treating diabetic injuries. Tagging the post \#SaveAFoot \#SaveALife, he prefaced it with a pointed note reading "permission granted by clients to share" and stitched the images of feet to a larger photo of a T-shirt that said:

BEHIND EVERY PERSON WITH

DIABETES

THERE IS AN EVEN

STRONGER

FAMILY WHO STANDS BY THEM

SUPPORTS THEM AND

LOVES THEM

WITH ALL THEIR

HEART

"It seems as if the exotic things get the attention. . . Having five people with Zika brings the media. It's very sexy, it's exotic, it's front-page news. People getting their limbs cut off — not really exciting," Dr. W later reflected on diabetes, and the difficulties he has had for decades trying to bring public attention to the illness. In his words:

I think the problem is that in this world of sound bites, diabetes is not that impressive or sexy. But the damage it does is absolutely horrific . . . diabetes is expanding and growing at an alarming rate. It's chewing up your GDP. It's smothering countries. It's something that's really killing how your health system will work in every way. ...

I think the problem is that it's not studied. People don't really know how many amputations are going on. First, there is an occult number: a number 
not well known. Number two, the long-term effects of it are not well studied in this population. Number three, the transgenerational issues that go along with that. The fear, the worry, the anxiety, the denial. . . . No one is measuring that. It's just like, yeah, diabetes. It's in this area.

In the U.S context, for which better data exists, about 80 percent of the country's total amputations result from diabetes. But as Dr. W predicted, it proved nearly impossible to find solid numbers about how many people in the world lose limbs to diabetes each year. As one journal article about this global data gap recently summarized: "Internationally, accurate numbers of limb amputations performed are very difficult to estimate as there is no recognized database or organization collecting this information" (Neil 2016, 107).

Yet even geographically narrow studies suggest some jarring numbers: In North American contexts, about a third of people with diabetes experience an ulcer, and more than 50 percent of diabetic foot ulcers become infected (Armstrong, Boulton, and Bus 2017). A third of people who seek clinical care for ischemic diabetic ulcers (the most common type) will die before their injuries ever heal. Diabetic foot ulcers "have morbidity and mortality rates equivalent to aggressive forms of cancer" (Armstrong et al. 2013). After diabetes-related amputations, more than 70 percent of patients die within five years - a death rate second only to lung cancer. Following a major diabetic amputation, 50 percent of people will have another limb amputated within two years (Armstrong, Wrobel, and Robbins 2007).

Tellingly, some of the best statistics about the global severity of diabetic injuries have been collected by accident. Diabetic amputations have often turned out to be the number one cause of limb loss captured by databases meant to gather information about landmine blasts and other war-related injuries, as reported in studies with titles like "Diabetes or War?" (Yaghi et al. 2012). As one team of physicians (Armstrong et al. 2013, 1817) notes: "There is a lack of federally and not for profit-funded research directed toward diabetic foot ulcers. This funding gap is disproportionately large in comparison with the public health impact of this sequela." They call this "a clear and present medical and fiscal calamity. We must mind this gap as a locomotive of lower-extremity complications is approaching."

This odd turn of phrase underlines a strange fact: if the injuries and amputations that their team analyzed had been caused by actual locomotives, they would be robustly included in the global statistics that guide health policy funding. The development over recent decades of "Global Burden of Disease" reports, for 
example, was designed especially to attend to the daily difficulties of living with chronic injuries. Its scale of "disability weights" emphasized the devastating toll of amputations on daily life. But the possible causes of amputations and related injuries that such studies painstakingly charted historically did not include diabetes. It did, however, estimate global amputation burdens for six kinds of traffic accidents (motor vehicle; motorcycle; bicycle; pedestrian; mass transportation, including bus and train; and other road incidents), as well as animal bites, domestic violence, gunshot injuries, self-harm, war, and torture (WHO 2009; Haagsma et al. 2016). These statistics led the report's authors to conclude that global injuries were declining and that the world today was becoming a safer place. I wonder for how many countries in the world, besides Belize, that sounds incomplete.

A report from Belize's only prosthetic leg clinic noted that of the six amputations attributed to animal bites the previous year among Belize's tiny population (280,000 at that time), only three had actually been venomous snakes. "The other three were attributed to rat bites becoming infected in diabetic patients. Bites from rats speak to the need for improved standards of living" (Kistenberg 2005, 38-39). The report added: "Most diabetics from [this] Belize clinic ambulated in flip flops, sandals or ill-fitting footwear due to poverty. In addition, they reported having their blood sugar tested once every three months! This very likely contributed to their becoming amputees in the first place" (Kistenberg 2005, 41).

These masked numbers have consequences in real life because they guide global funding priorities. Last time I visited Belize, I went to see a few friends one weekend and found that three of them had lost a leg since my last visit. The repetition was becoming so normalized that anxieties about someone "getting cut" came up constantly in conversations. The pattern did not require an epidemiologist to notice that something was wrong. Of course, not everyone with diabetes dealt with limb injuries or losses. But every family living with it did have to be constantly on guard, and those stakes felt high.

Amputations due to diabetes complications get labeled as "non-traumatic" because they take shape slowly. Yet slow timing can sometimes make required procedures even more harrowing for patients. In hospitals around the world, when it comes to supposedly non-traumatic diabetes wounds, tough choices get made at the time of amputation. For instance: surgical teams must decide whether to use limited supplies of anesthesia to render a patient unconscious, or only to numb them at the waist. In the latter, the conscious version, patients are awake and listening to everything. Bone has to be screwed to the table before being sawed. One woman in Dangriga told me she prayed so hard and felt her family's love so palpa- 
bly that when the drill started up, she felt grace take over completely, and her ears filled with a loud ringing so beautiful that it became the only noise in the room.

"There are so many miracles," she told me. "Thank God."

\section{DISPLACED SURVEILLANCE}

Humans alive today, in general — and people of color, in particular (Browne 2015)_ are subject to constant surveillance. Algorithmic tracking and facial recognition tools are on the rise, alongside what Alondra Nelson calls "data spillover," cases in which things like saliva submitted for ancestry testing or photos shared on social media can become harvested as data by interested parties ranging from pharmaceutical companies to police forces (Nelson 2016). Companies and states have never collected more information about us. This made it feel even stranger to come across the rare issue where members of the concerned population actually expressly wanted institutional "surveillance" collected — only to find that this data remained elusive.

As one prosthetic limb-maker in Belize noted: "A lack of surveillance in Central America has stalled the development of amputation prevention services" (Kistenberg 2005, 16). This lack of published data on diabetes' more severe manifestations shows what João Biehl $(2007,204)$ has called "technologies of invisibility," making it difficult to be "seen by the state" (Street 2012) and allied transnational institutions. It's a familiar catch: it takes numbers to redirect global policy money, but it takes global policy money to assemble the numbers (Sangaramoorthy and Benton 2012; Benton 2015; Adams 2016; Biruk 2018).

Belize has made more headway around these uncomfortable numbers than most Central American and Caribbean countries. Uldine Wright, a concerned physician, recently published a very small study incorporating data from Karl Heusner Memorial Hospital (Belize's only tertiary care hospital). She recounted a tally showing that among patients who came to the Belize City public hospital to treat a diabetic ulcer (often caused by an ingrown toenail or a similarly tiny wound), 89 percent received an amputation (Wright 2017, 25-26). Around 29 percent lost their leg below the knee, and 24 percent above the knee. Eighteen percent of amputations were transmetatarsal (toes or fingers with a piece of the foot or hand), while another 18 percent only lost digits (mostly toes). Debriding allowed 12 percent of patients to heal, but conservative treatment had a 0 percent success rate (Wright 2017, 26). The second hospital studied by Wright showed a less pronounced but still alarming figure: here, 24 percent of patients who arrived for diabetic foot care received amputations. 
Even a tiny snapshot sample like this suggests a sense of how normalized injuries impact care across the board - physicians upset with patients for not coming in earlier, patients terrified to seek care when they know rather accurately the probability of returning with an amputation. Tensions existed about precisely which cuts were avoidable or possibly inevitable, everyone struggling to bear their piece of the intensity.

Long after she officially retired, Nurse Elizabeth had kept going to the hospital to help with diabetes foot care. She also made certain home visits, even though she no longer got paid for the work. She heard that specialized diabetes foot training will be coming soon, and said she will start to relax her watch if she gets an apprentice. In a rural district where so many were losing limbs, how else could the only person certified in foot care training truly retire?

From what I could observe, the caregivers most routinely dealing head-on with diabetic injuries were mostly Black and Indigenous women. They made up the majority of the community health volunteers, nursing, and medical attendant care workers with whom I spoke. They provided formidable expertise, but their labor offered little way out of the intense sensorium in which rural health workers practiced their craft. It took time to learn unwritten care strategies, a Garifuna rural health worker named June explained to me as she recounted the story of the first time she cared for a diabetic foot: "I just told the patient, I'll be right back!" The older Garifuna nurse with whom June was apprenticing later praised how artfully she had concealed the pause during which she went outside and vomited.

"If the patient sees that you are scared, they will be scared too." Nurses taught each other techniques to steel themselves when unwrapping a diabetic foot, since "you never know what is going to be under there": be ready for larvae, so that anything else is good news; take the cap off the bleach bottle before you open anything else, then just focus on the bleach smell. June described learning to swallow her dread while calming patients' reactions if they looked down, telling them stories about similar diabetic wounds that ended in recovery. "Laugh, don't cry," she added.

I once fell into conversation with a team of care workers in Belize wearing matching "EYES ON DIABETES" T-shirts. The printed design on their backs featured watchful eyes, and I found myself thinking about how the assumed optics of functioning public health surveillance had been displaced. In the gaps left in accurate foot care epidemiology by global and overstretched local institutions, these care workers, it seemed to me, were doing more than just "improvising medicine" to blunt the impact of diabetic injuries, with care practices full of the 
ad hoc force that Julie Livingston (2012) describes around cancer in a different part of the world. In addition to artfully patching together resources, members of these makeshift networks were improvising select forms of surveillance, akin to the multiplied perspectives that Robert W. Sweeny (2005) calls “para-sighted” optics - teaching each other new ways to see, keeping their own counts of emerging patterns, watching out for each other.

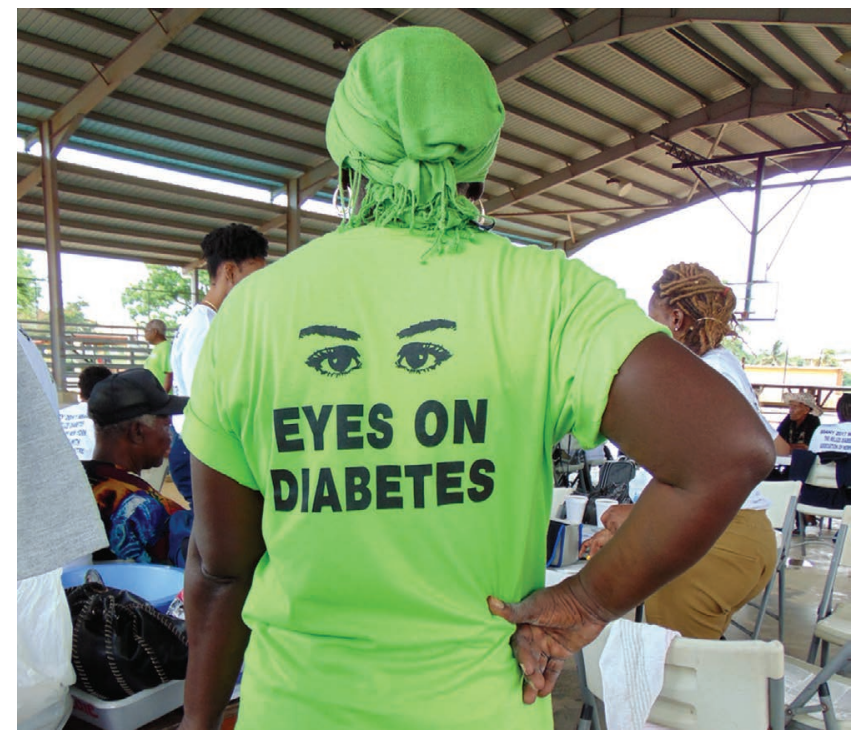

Figure 3. Nurse Elizabeth watching for anyone in need of foot care. Photo by Amy Moran-Thomas.

People I met improvised daily surveillance of their own bodies: obsessively checking their skin for scrapes or soft spots, engaging others to help check the bottoms of their feet, praying to spirits for assistance monitoring. The Foot Center Group with which Dr. W works recently launched a new program in the Caribbean: visiting the proprietors of nail salons to teach them signs of diabetic ulcers. This network of beauty shop technicians is now referring clients to hospital care when their hands and feet are in danger.

\section{MIXED METAPHORS}

In Illness and Its Metaphors, Susan Sontag (1988) famously described the disease metaphors that societies come to accept as common sense-despite the ways such associations often blame and shame patients for their own illnesses, and frequently do harm to people's sense of self and their possibilities for recovery. "Patients who are instructed that they have, unwittingly, caused their disease are also 
made to feel that they have deserved it," Sontag $(1988,57)$ worried. At the same time, she added, "we cannot think without metaphors" (Sontag 1988, 57).

For this reason I admired Dr. W's skill at inventing counter-metaphors, which he mixed unabashedly. Consistency in literal images is not his objective, just consistency in bodies.

"What really bothers me is the look of loss on a patient's face when you tell them the reason they are going blind," he said as we spoke one day at his home hospital in New York, after returning from the team's annual Belize visit. In the face of such injuries, Dr. W was willing to try on any metaphor on for size. "Diabetes is like fighting a bull. You need to grab it by the horns, or it can gore you." He explained that he had honed his skill at mixing metaphors over the years by talking with patients, learning what analogies seemed to stick and help families live with and manage their afflictions.

"You can't outrun diabetes, you can only outsmart it," Dr. W smiled. "That's a good one. It can be overcome, but not without a strategy." Different kinds of metaphors may prove strategic for different situations, he said. Many of his patients struggled with depression as their diabetes progressed, and what framings might help really depended on the individual person. Alongside photocopies of medical instructions, Dr. W's team kept on hand a variety of prayers for religious patients. At other times, it helped some people to cast diabetes as an external nemesis and frame the body as an epic terrain that required great care, but implied no connotations of personal shame: "When you enter the land of diabetes, Dracula is around." In Dr. W's words:

Phantom pains after an amputation: the trauma over and over of feeling a limb still there and seeing it is gone. It tricks your body. Diabetes is the great magician. It gives you illusions, hunger and thirst you can't satisfy. Diabetes is like a thief, or a trickster. It is a thief of limbs. It is a tragedy that keeps happening. Patients getting cut into pieces. It hits like an asteroid. It changes like a chameleon. As soon as you think you know what it looks like, it will change shapes and hit you in another form: it's high blood pressure, it's kidney disease, it's blindness, it's a toe. It keeps morphing. It lives with you. It lives in you. It's almost like it's a virus, hiding.

Driving home that evening, I kept replaying Dr. W's eerie images in my mind. "Our bodies prime our metaphors," James Geary (2011, 100) observes, "and our metaphors prime how we think and act." I wondered how policies guiding 
public perceptions of diabetes might differ if based on Dr. W's descriptions of a volatile and difficult-to-defeat shape-shifter. His creative descriptions struck me as efforts toward what Charles L. Briggs and Clara Mantini-Briggs (2016) call "communicative justice" — working at the junctures of storytelling about health conditions to try to change the ways they biologically manifest in bodies. One image, in particular, I found myself returning to again and again: almost like a virus, hiding. Not quite like a virus. Slow, cumulative. But in certain ways . . . almost. In contrast to the rest of Dr. W's figures, that was an image of diabetes I had encountered many times before.

\section{PARA-COMMUNICABLE CONDITIONS}

I was initially surprised that rumors of contagious diabetes seemed to spread, rather than subside, as time wore on and people in Belize became more familiar with the illness and observed it more closely in their own communities. Public health authorities often cite education about causality as one of the most important tools to curb diabetes. But in this case, it was not that people had never received diabetes education; it was that the one-size-fits-all biomedical education did not always square with the realities they saw over time. Diabetes moved like an epidemic. It killed like an epidemic. In the Stann Creek District, diabetes affected ten or twenty times more people than HIV/AIDS, and everyone knew that AIDS was an epidemic. Diabetes was spreading quickly in local communities, often mingling with and amplifying infectious conditions. But a non-transmissible disease was not supposed to spread, let alone outpace its contagious comorbidities. So what was happening in between local patterns and the biomedical explanations for noncommunicable conditions? Many people had learned and considered the classic biomedical account of diabetes as non-transmissible — but at times, this account did not align with their lived observations and evident bodily realities.

As the historian Allan M. Brandt $(1997,56)$ notes, "the problem of causation is critically important because it reflects directly on the fundamental moral issue of responsibility for disease." This point hit home more concretely for me when I gave a public presentation on an early version of this project's findings one morning to a small crowd in Dangriga. The audience came mostly from local branches of the BDA and from HelpAge, a crucial organization providing supportive care for aging. I began our conversation that day with a cursory slide showing the WHO map of diabetes deaths. I had assumed that everyone would already know this part, but the map seemed to be the only image I showed that surprised anyone. People raised eyebrows at each other. Wait, versions of this are happening across the world? 
Some people reflected later that they had gotten so used to stories attributing the rise in diabetes to their local cultural foods or their personal "lifestyle" responsibilities alone that it shook up their perspectives just to take a step back and think of diabetes as an epidemic — a much bigger story, whatever that might mean.

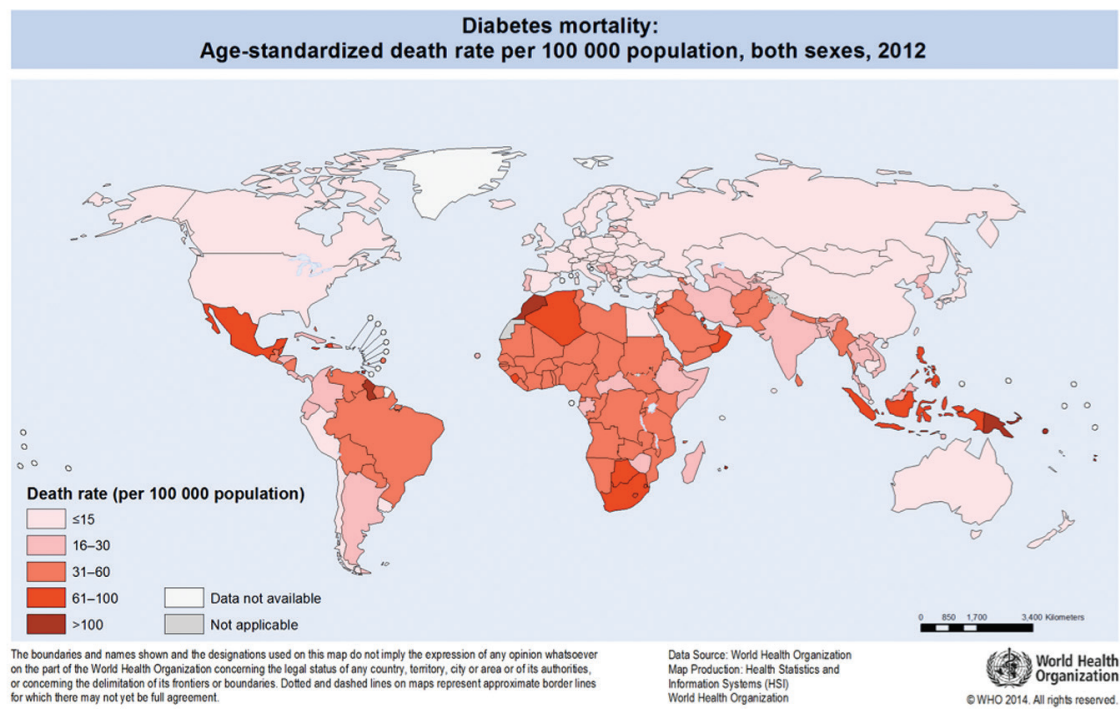

Figure 4. (C) 2014 World Health Organization. "Diabetes Mortality: Age-Standardized Death Rate per 100000 Population, 2012.” Map reprinted with permission. Available at the World Health Organization Map Library, accessed April 22, 2018, http: / gamapserver.who.int/mapLibrary/ Files/Maps/Global_NCD_mortality_diabetes_2012.png.

There is a lot on the line in "explaining epidemics," as the historian Charles E. Rosenberg (1992) once put it. Didier Fassin (2011) and others have examined the way global aid resources tend to move according to the moral rationales of humanitarian "crises." This kind of intervention "has come to define itself through exception,” Peter Redfield (2013, 72) aptly observes, though that framing quickly "loses its transcendent magic" when "diseases prove chronic." One woman in Belize described to me how a team of U.S. medical students visiting her village had been fascinated by her ankle wound when they believed she had leishmaniasis (a tropical disease caused by sandfly-borne protozoa parasites), but stopped visiting her when it turned out to be a diabetic ulcer. As Priscilla Wald $(2008,3)$ notes in Contagious, senses of urgency are deeply contoured by "how both scientists and the lay public understand the nature and consequences of infection, how they imagine the threat, and why they react so fearfully to some disease outbreaks and not others at least as dangerous and pressing." 
The perceived non-urgency of diabetes intersects with questions of uncertain chronic causalities (see Agard-Jones 2015; Shapiro 2015; Murphy 2017; Nading 2017). Today, molecular pathologists working with population-level data describe "the new toxicology paradigm of endocrine and metabolic disruption" that reframes diabetes as a "hidden cost" to pollution exposure (Neel and Sargis 2011, 1846). This phenomenon was first grasped largely through industrial accidents: for example, diabetes rates in a small town in Italy spiked in the twenty years after its chemical plant exploded (Bertazzi et al. 2001). A recent long-term study of 1.7 million U.S. veterans estimated that about 14 percent of diabetes cases could be associated with air pollution alone, regardless of what foods individuals ate (Bowe et al. 2018).

Reading such studies, I kept recalling the sand and ocean waves filled with bits of plastic, and how it takes decades for food containers to photo-degrade into the tiny slivers found on the beach. Little pieces get eaten by fish, moving up the food chain and seeping into water, often leaching BPA also associated with diabetes risk (Vogel 2009). Another study of 3,080 farmworkers in rural India found that exposure to organophosphate chemicals contributed to diabetes, apparently because the insecticides designed to kill crop pests also interacted with the living microbes crucial to metabolic balance inside people's digestive tracts (Velmurugan et al. 2017). This constitutes only one of several mechanisms by which endocrinedisrupting chemicals can contribute to diabetes, a disease of the endocrine system (see Colborn, Dumanoski, and Myers 1997). As Harris Solomon (2016) details, the metabolic absorptions that connect human bodies and larger environs include a range of biological mechanisms and ecological exposures. These compounding contributors can include hunger- and stress-related epigenetic modulations (Geronimus et al. 2006; Lamoreaux 2016), and how individual humans' eating constitutes only one way of framing nested metabolisms (Landecker 2013) that interconnect people, plants, and animals. Amid these complex interactions, diseases are not binary either-or conditions. They emerge from uneven landscapes of exposure with many kinds of transmissions.

The popularization of infectious disease mapping often gets celebrated in public health classes today as linked to John Snow's team identifying and interrupting patterns of water-borne cholera in London. ${ }^{2}$ But the flip side of this discovery also proves instructive: the moment that infectious pathogens were becoming legible, some tried to cast this model as the only way that disease-causing exposures should matter: companies tried to use this as a shield to avoid responsibility for industrial harms. As early as 1855 , Snow was called in a legal case about deregulat- 


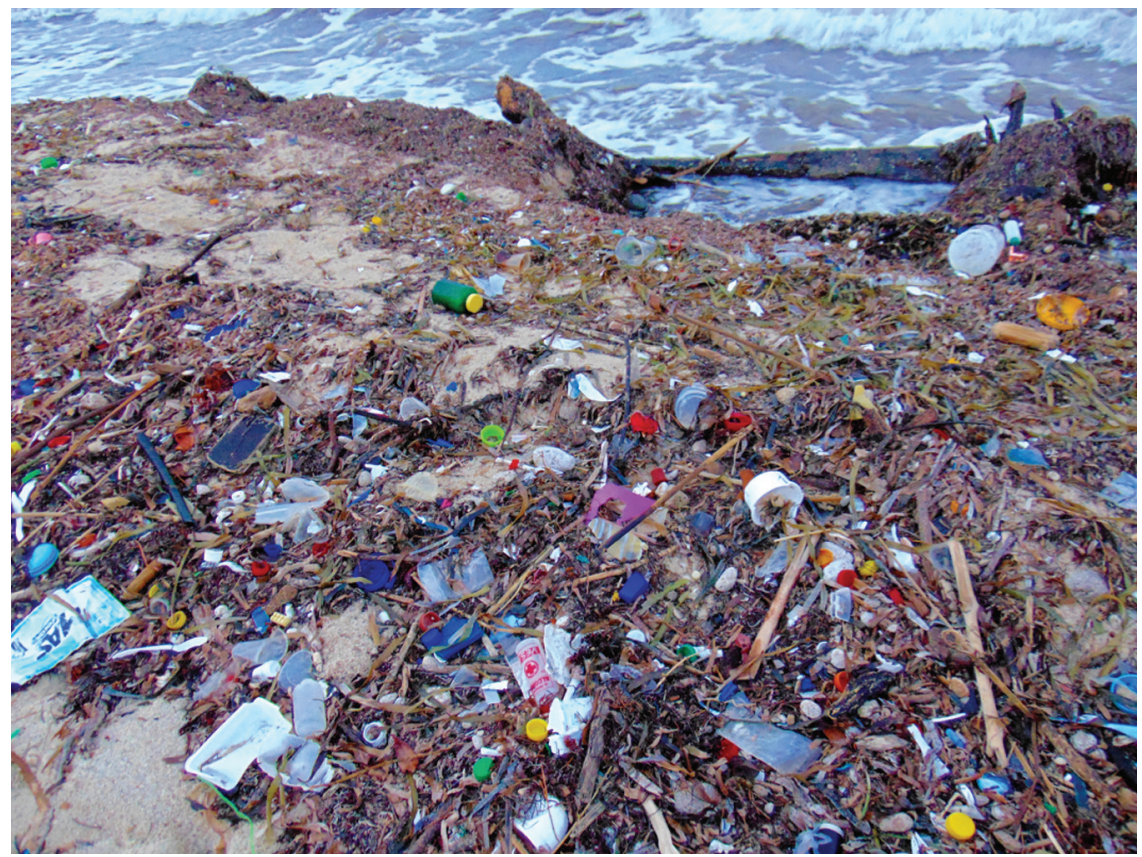

Figure 5. Plastics washing up along the shoreline, southern Belize. Photo by Amy Moran-Thomas.

ing industrial pollution from factories. He testified that chemicals could "not cause disease; those poisons do not reproduce themselves in the constitution" (Lilienfeld 2000, 5). When prodded further about reported symptoms of toxic exposure among workers, Snow responded: "Persons are often very much influenced by the imagination."

To approach escalating chronic disease patterns, we need ways to recognize and publicize potential exposures of processed diets and industrial toxins, as well as biological germs - an epidemiology of what Adia Benton (personal communication, 2018) has called "connectors," rather than vectors alone. That nexus requires attention, as Michael M. J. Fischer (2013, 347) emphasizes, to the situated "bioecologies at play" between porous boundaries and reactive membranes, human and environmental health (Petryna 2013; Todd 2017; Niewöhner and Lock 2018).

For this task, either-or labeling of contagious versus non-communicable disease proves insufficient to describe the prevalence of human-made diseases now becoming prominently visible around the world (see Seeberg and Meinert 2015; Moran-Thomas 2010). Diabetes is not an exception to, but iconic of growing chronic epidemics — such as cancer clusters (Jain 2013; Walley 2013) or the soaring prevalence of asthma and other autoimmune conditions (Fortun and Fortun 2005; Whitmarsh 2013; Kenner 2018). Talking to public health practitioners and 


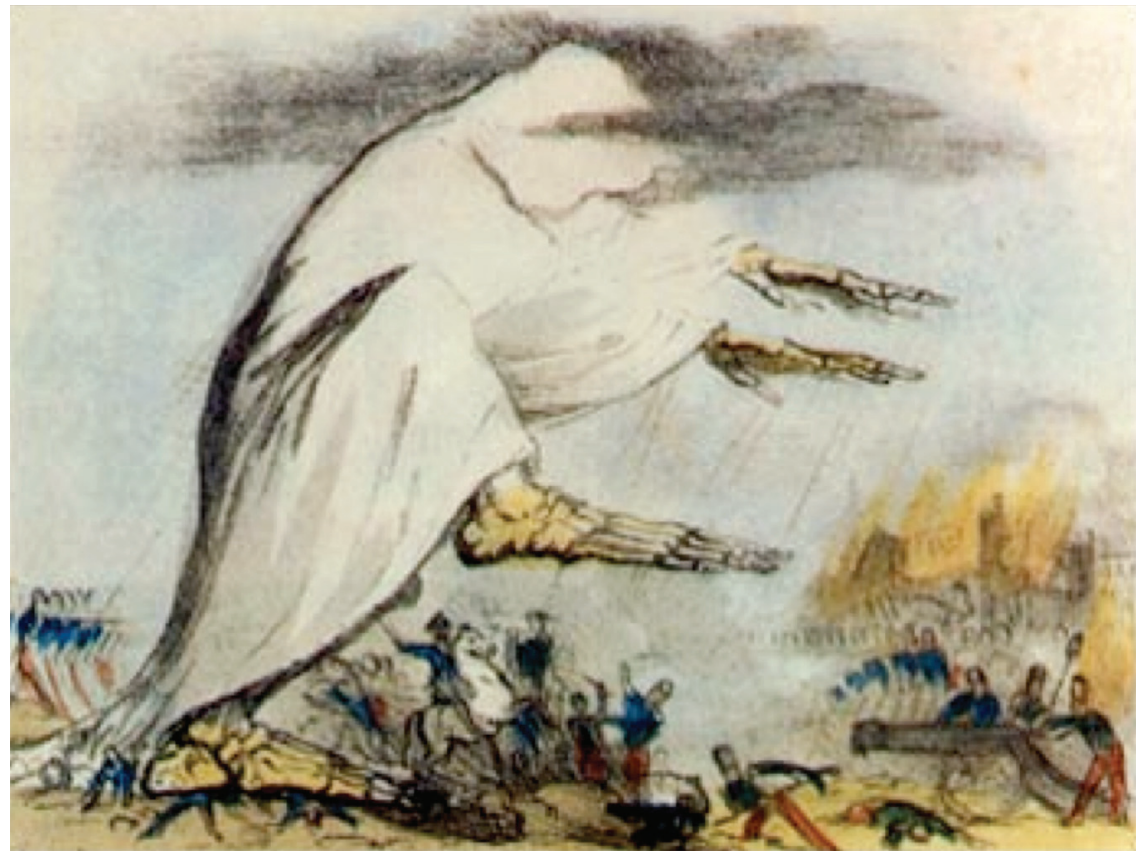

Figure 6. Miasma, 1831, as depicted by Robert Seymour. Courtesy of the National Library of Medicine.

policy makers about diabetes, I found it helpful to have a different name for this in-between territory of exposures, and came to describe it as para-communicablechronic conditions that may be materially transmitted as bodies and ecologies intimately shape each other over time, with unequal and compounding effects for historically situated groups of people. Exploring this idea has become a way to triangulate between different spaces of knowledge making-such as academic conferences where keywords to describe exposure were plentiful, to the arenas of clinical practice where they were often illegible or simply fell out of frame.

To be sure, any chronic exposures of stressful climates and the chemical contamination of food, air, and water only compound more commonly recognized issues related to limited access to healthy foods. And of course, industrialized food products can cause harmfully high blood sugar levels through their depleted nutritional content, too. "How am I going to make a diet? There is only one kind of food here," I often heard patients tell the visiting Cuban physician, who would laugh kindly but never really had an answer. In neighboring Guatemala, Emily Yates-Doerr (2015) observed that nutrition experts often carefully avoided describing problems of macro-infrastructure that neither they nor their patients could change, because that advice could have registered as cold or uncaring. Care- 
givers I met similarly tried to avoid depressing conversations, in hopes of generating a healthy sense of optimistic possibility — focusing on the scale within their grasp. This usually meant trying to equip patients to negotiate existing foodways. But who will rework larger food systems?

Foods contributing to diabetes are often familiar across global markets - sodas like Coca-Cola are only the most iconic of many processed foods containing sugar, white flour, and white rice. In contrast, every local diet dismantled by these industrial diets is unique-meaning that any advice about eating requires local texture to prove meaningful for people (see Wilk 2006). One morning, I joined a group in Dangriga that gathered to share cooking ideas to modify Belizean and Garifuna dishes for those with diabetes. They wondered if local labs could receive the resources to investigate the nutritional content of certain dishes, or to monitor the fish and water for traces of toxic chemicals.

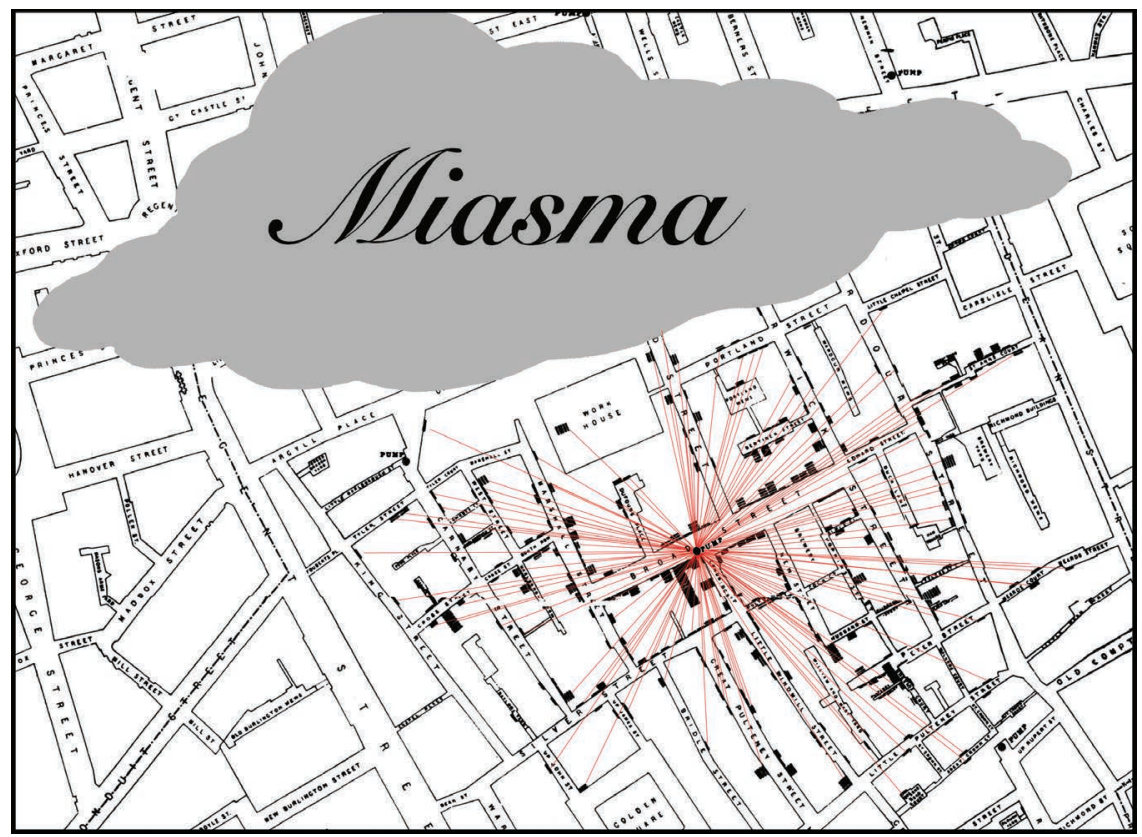

Figure 7. Map of 1854 London cholera epidemic by John Snow, with illustration contrasting miasma and contagion models by James Young.

Sometimes it feels like a miasma cloud to live in a hazy sense of ambient riskyet at the same time, cloudiness can be strategically used by industries to obfuscate accountability (Nash 2007; Langston 2010; Nestle 2015). Such corporate strategies complicate the ways in which anthropologists might grapple with uncertainty. For instance, key theorists of "syndemic" models_-describing how multiple epidemics 
interact - recently expressed concern that the term can take on a miasma-like cloudy quality if it is taken up imprecisely, or without follow-up steps to trace specific pathways and signatures of responsibility (Mendenhall and Singer 2019). Anthropologists like Elizabeth Hoover (2017) and Elizabeth F. S. Roberts (2017) engage the work of collectives seeking ways to build a counterscience, through sustained collaborations and a grassroots-guided "science of the in-between."”

I initially thought it would be fairly easy to apply for a grant to support the kind of local projects that people in Belize suggested. Yet it turns out that certain prominent diabetes grants explicitly decline to fund research that generates locally relevant dietary and care translations; they reason that such outcomes would not be globally "generalizable." Yet diabetes prevention relies on locally specific texture to gain traction and uptake. If only approaches imagined as "generalizable" receive policy funding, then most well-resourced interventions will end up framing what is happening with individuals as the problem.

In light of this, it seemed as though Grace's hurt foot examined that day not only spoke of gaps in the surveillance around diabetes-related injuries, but also of missing watchfulness throughout larger global systems of food and medicine. The scene evinced a culmination of decades or centuries of policy and legal regulations that contributed to chemicalized water, air, and foodways, as well as skewed options in food availability, agricultural systems, and land law-compounding moments that intersected with underresourced care to culminate in debility.

Some months after we last saw each other, I learned the painful news that Grace had chosen to die with all her limbs attached. After careful reflection, she had made the decision to refuse the amputation of a gangrenous leg. "More people are doing that now," Nurse Elizabeth said when she told me. Looking for a picture of Grace to send to her family, I found only a terrible archive of her feet. My mind kept returning to Dr. W's words from that day, when he wished aloud that there could be some way to get Grace to a hyperbaric chamber.

\section{WEATHER}

Not only did the infectious/non-communicable dualism often appear illsuited to capture a full picture of diabetes causation, but a looping effect seemed to be catalyzed by these attributions: certain diseases' "geography of blame" (Farmer 2001, 97) can materially shape institutional funding and access to extant medical technologies. I came to see para-communicability as the partially connected set of ways in which etiology, treatment, morbidity, and mortality are imagined and enacted. The compounding effects of these health atmospheres — often highlight- 
ing differences linked to compounding stresses and absorbed environs - together evince the unequal "climate that produces premature Black death as normative" that Christina Sharpe $(2016,102)$ calls "the weather." In fact, "pressure" is not only a common name for stress in much of the world-barometric decompression machines are literally a key method of injury care and amputation prevention.

At some point I started to think of decompression chambers as almost mythical places. Originally developed in the late 1800s in England for recreational and military scuba diving, hyperbaric chambers became widely used in hospitals for chronic wounds in general (and diabetic ulcers in particular) in Europe and North America throughout the 1960 and 1970s (Lucas 1967). Their physics resembles going deep underwater: the pressure inside hyperbaric chambers is gauged in technical units called ATAs, absolute atmospheres of pressure. At sea level, you are at 1 ATA, experiencing one atmosphere of pressure. Inside a hyperbaric chamber, each additional atmosphere corresponds to the pressure of being underneath thirty-three feet of seawater. This pressure helps saturate blood plasma with healing oxygen. (Plasma is the hay-colored fluid in which more familiar components of blood, such as platelets and red and white blood cells, travel through the body, helping vascular tissues heal.) Even the most stubborn diabetic wounds might have a chance with this boost of intensive oxygen under pressure.

Bodies that stop healing are hard to imagine. Even a minor cut or scrape can be unable to form a scab or shrink a little each day. For months, even years, a tiny abrasion might look as though it had just happened, almost as though the injury is frozen in time, except that it can still become infected. Preventing infection is work that starts anew each day. But even very old diabetic wounds can start to heal again if given time in a hyperbaric chamber. Some studies have suggested that oxygen therapy is helpful not only for wounds, but even for preventing the onset of diabetes in the first place.

These devices activate the body's healing capacities through the saturation of oxygen-rich air, either directly inside the chamber or through masks. In the United States, some versions are even marketed for pets, I realized as I read about access advertised for "equine athletes and pleasure horses." Some masks look like the clear bubble helmets intended for astronauts, while others appeared to me nearly indistinguishable from scuba masks or nebulizer tubing. Multiperson hyperbaric chambers can be sizeable, like a clinical waiting room with round submarine windows; others resemble an appliance like a huge microwave with seating inside for three to five. 
Researching the varieties of decompression machines, one day I realized with some shock that there actually had been a hyperbaric chamber in Belize all along. A chamber has been available for decades in a network sustained by Ambergris diving shops, in case any scuba divers experience the bends or other pressurerelated issues. As an additional safety measure, a second hyperbaric machine was recently added to serve diving tourists on the island.

It turns out that the phenomenon of diabetic limb injuries across the Caribbean coincides with a coral reef geography and associated tourist economy now particularly well-equipped with hyperbaric chambers. According to websites like Caribbean Adventures and Dive Vacations, Barbados, Belize, Cuba, Dominica, Dominican Republic, Dutch Antilles, Jamaica, Martinique, Mexico's Cancun, Puerto Rico, Saba, St. Lucia, and Trinidad and Tobago (among others) all have hyperbaric chambers, usually located in places citizens would not think to turn to for diabetes care, such as marine parks, fisheries, army bases, and scuba-affiliated clinics. Trying to digest this information after watching a video of one in Barbados, I asked Dr. W if he had time for a phone call, to make sure I was not misunderstanding.

"Are these the same machines that can prevent diabetic amputations?" I asked him.

The short version of his answer was "Pretty much . . . but it's really complicated." The long answer would be something anthropologists might call a sociotechnical problem, since it is difficult to separate technological limits from the way human societies position and use their devices.

In the United States, health insurance often covers hyperbaric treatment for diabetes ulcers, billing about $\$ 350$ per dive as long as the specialist is accredited by the Undersea Medicine and Hyperbaric Society. But in lower-income parts of the world, insurance reimbursement apparatuses are more complicated and oxygen more expensive per tank. And diabetic sugar's wounds, unlike a diver's bends, are almost never a onetime fix. Additionally, most scuba divers with decompression sickness quickly recover. But the most serious diabetic ulcers might require session after session of dialing the machine up to three ATA - the pressure of being under about sixty-six feet of seawater. This means more compression and more oxygen - and thus more cost and possibly greater risk, since decompression therapy always carries the rare (but ever possible) side effects of seizures or a serious issue caused by the intense pressure. It is best to be near a full medical facility, or with a range of specialists in case something goes wrong.

Dr. W felt hopeful that more portable devices featuring aerosolized oxygen in transportable bags may become accessible for diabetic wound treatment around 
the world in the near future. He sent me a link for a YouTube video showing the new technology, and we left it at that. From what I could read between the lines of "it's really complicated," Dr. W's decades of work throughout the Caribbean had taught him that a portable device would work well for his team, but it had not proven easy to open up conversations about getting citizens access to the infrastructures of hyperbaric chambers already present in their own countries.

For instance, when a man named Tobias had texted Dr. W a picture of the bone that had fallen out of his foot, the only thing that their team of physicians could think to do was invite him to travel 3,000 miles from Belize City to New York. The treatment for Tobias's foot lasted more than a year. Treatment with Dr. $\mathrm{W}$ and his colleagues included not only dozens of sessions in a hyperbaric chamber but also a wound VAC (vacuum-assisted closure), antibiotic beads, and grafts to treat the bone infection. Dr. W helped Tobias find a place to live near the hospital, and his network of colleagues found a way to cover the treatment costs. Tobias's neighbors and family all chipped in to help with his plane ticket.

$$
* * *
$$

Human solidarity is an elusive thing. One of the most famous early thinkers to theorize it was the sociologist Émile Durkheim. It is a lesser-known fact that Durkheim's influential ideas about social coherence were shaped by his obsession with his era's emerging scientific insights into the behavior of infectious bacteria (Wald 2008, 14-15). He suggested that community and communication shaped each other-since social groups impact how perceptions turn into concepts "communicable to a plurality of minds" (Durkheim 2001, 619). In this view, communicability - the ways that biological conditions are transmitted between bodies - is impacted not only by our communication about them, but also by the communities that take shape (or not) to respond.

This, too, proves integral to what I came to see as the para-communicability of diabetes: not just a different paradigm of causality but also a more comprehensive model of public response; "not to ignore difference, but to create alterrelations with one another" (Simmons 2017). The availability of hyperbaric chambers for scuba divers is designed to offer a safety net, so that pleasure-seekers can indulge in risk yet have the option of rescue if threatened by death. This same logic of care was not, however, extended to those dying from diabetic injuries. Between these two scenarios lurk many uneasy questions: What counts as an extraordinary measure, for whom? Whose lives are valued as worth rescuing, at what cost? 
Community can be as much about disconnections as connections - the lines and distinctions drawn when people order and categorize their worlds. According to disease theory, infection is part of the price we pay for living in association with one another, and for our many eager forms of exchange. But only some connections get recognized, while others remain overlooked, both when reckoning causation and when sharing stories of care that might impact future access. In the end, perhaps the diabetes epidemic is not so much illegible as legible in different ways from different perspectives. Dr. W, Nurse Elizabeth, and many caregivers and patients I spoke with said they hoped essays like this one might offer a small next step toward public or media recognition of the injuries they are encountering, and the misrecognitions they highlight in our received models of causality and care work. In the meantime, the conditions they deal with on the ground often align with the very figure James Baldwin $(1998,83)$ used to capture the effects of chronic racism: "One is always in the position of having to decide between amputation and gangrene."

When I called the largest hyperbaric clinic in Belize, I learned that their multiperson machine simulates dives of up to 165 feet deep. A well-trained physician remains onsite. When I asked whether it could be used to treat diabetic injuries, the curator replied yes: scuba divers at times received care for coral injuries, and such therapy sessions could also be used on other wounds. She added that for patients with U.S. health insurance, the co-pay went down to US\$100.

It has become customary in some conversations to talk about globally unequal health infrastructures in the language of the global North versus the global South. Yet this geography takes on more complicated shapes when trying to describe the outposts of either U.S. insurance-accepting technologies available to those in the know in Belizean divers' clinics, or the checkered maps of cities like New York and Los Angeles, where diabetic amputation rates increase in correlation with poverty and segregation. Hyperbaric chambers offer another uneasy reminder that even in the same places, we live in segregated atmospheres-racialized inequalities that pattern out both inside the United States and in countries like Belize across the world.

My first impulse was to visit one of the chambers, as if describing it would resolve the contradiction. I had never been to San Pedro, and wondered if Elizabeth might go with me. But when I broached the subject as we chatted one morning, Elizabeth explained that she had never heard of that machine, and did not think one existed in Belize. I looked down at my notes from the dive shop, strug- 
gling to put its price list together with the insights from someone who had spent many years in diabetes wound care - all the patients whom Elizabeth had pulled back from the brink of loss over the years, and all of those like Grace whom she had seen die without hearing of any possible remediation measures that existed.

It did not feel right to press harder about the idea of a trip together. But I found enough words to repeat to Elizabeth how the machine resembled the one Dr. W had used to treat Tobias's foot in New York. The phone line got silent for a minute. We probably each had our own doubts and fantasies about the potential of such an elusive apparatus. In the moment of quiet, I wondered if Elizabeth was trying to imagine it too: the pressure, the oxygen, the slow hours of boredom and excitement; the blood starting to move again through skin and tissue that appeared dead; the feeling, if sensation starts to come back.

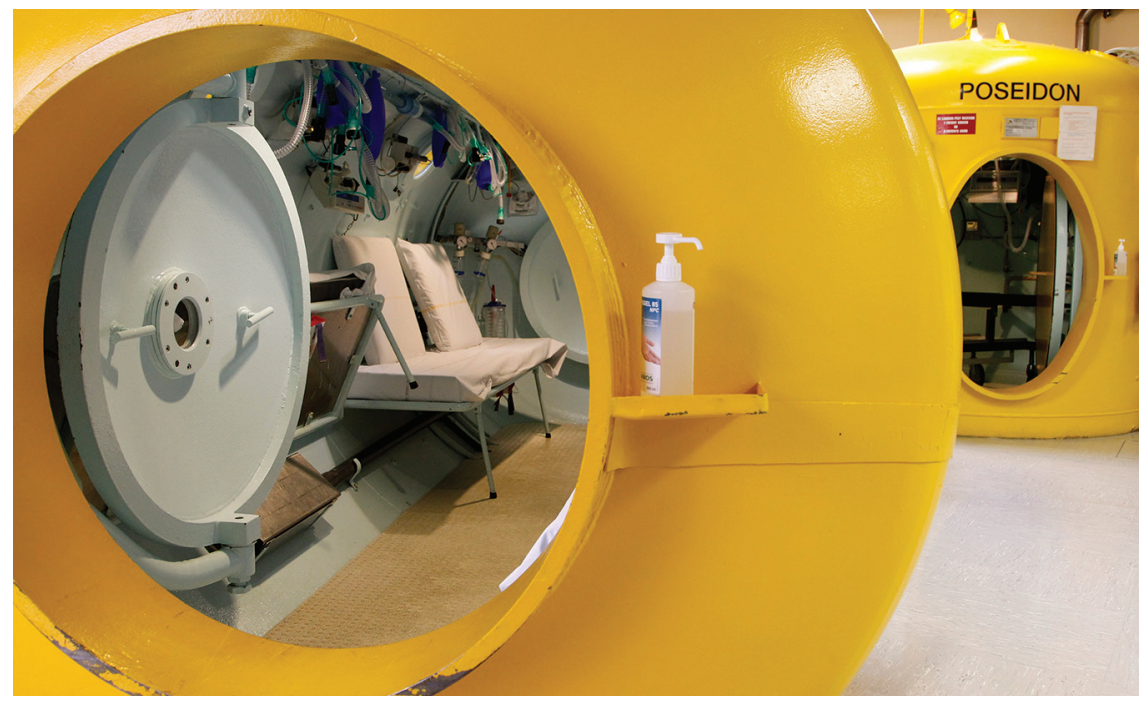

Figure 8. Stock footage of a hyperbaric chamber. Photo courtesy of BSIP/Getty Images.

\begin{abstract}
Long-accepted models of causality cast diseases into the binary of either "contagious" or "non-communicable," typically with institutional resources focused primarily on interrupting infectious disease transmission. But in southern Belize, as in much of the world today, epidemic diabetes has become a leading cause of death and a notorious contributor to organ failure and amputated limbs. This ethnographic essay follows caregivers' and families' work to survive in-between public health categories, and asks what responses a bifurcated model of infectious versus non-communicable disease structures or incapacitates in practice. It proposes an alternative focus on diabetes as
\end{abstract}


a "para-communicable" condition - materially transmitted as bodies and ecologies intimately shape each other over time, with unequal and compounding effects for historically situated groups of people. The article closes by querying how communicability relates to community, and why it matters to reframe narratives about contributing causalities in relation to struggles for treatment access. [chronic disease; diabetes; communicability; knowledge production; debilitation]

\section{NOTES}

Acknowledgments I am so grateful to all those in Belize and beyond who contributed to this project and commented on drafts. Grace's name is among those changed here for privacy, but this is offered with love in their memory. Special thanks to Nurse Elizabeth, the many branches of the Belize Diabetes Association, and to Dr. W and the Diabetes Foot Center Group, in collaboration with the Caribbean Diabetes Initiative. I am deeply appreciative for the support of my mentors in the Belize Ministry of Health and Institute for Social and Cultural Research, to my teachers in the Princeton Department of Anthropology who helped to launch this project, and to my wonderful colleagues in MIT Anthropology. For research and writing support, I also owe great thanks to the Wenner-Gren Foundation for Anthropological Research, a Mellon-American Council of Learned Societies Fellowship, the Princeton Center for Health and Wellbeing, and the MIT School of Humanities, Arts, and Social Sciences (SHASS) Research Fund. Special thanks to the peer reviewers and editorial collective at Cultural Anthropology for incisive feedback that sharpened this essay.

1. Sugar is also a common name for diabetes around the world, carrying distinct valences in each local social fabric (see Moran-Thomas 2019; Weaver 2019; de-Graft Aikins forthcoming).

2. Historians of science recount a far more detailed version of this paradigm shift (see Porter 1999; Worboys 2007).

3. This formulation comes from a panel discussion at the 2018 American Anthropological Association (AAA) meetings, where Lawrence Cohen (2018) offered comments in conversation with the work of Roberts and others working on themes of "Communicability in Crisis."

\section{REFERENCES}

Adams, Vincanne, ed.

2016 Metrics: What Counts in Global Health. Durham, N.C.: Duke University Press.

Agard-Jones, Vanessa

2015 "Chlordécone." Case presentation at "The Manufacturing of Rights," Beirut, May 14. https://www.youtube.com/watch?v=yvqVkR4Iuqs.

Armstrong, David G., Andrew J. M. Boulton, and Sicco A. Bus

2017 "Diabetic Foot Ulcers and Their Recurrence." New England Journal of Medicine 376, no. 24: 2367-75. https://doi.org/10.1056/NEJMra1615439.

Armstrong, David G., Vikram A. Kanda, Lawrence A. Lavery, William Marston, Joseph L.

Mills, and Andrew J. M. Boulton

2013 "Mind the Gap: Disparity between Research Funding and Costs of Care for Diabetic Foot Ulcers." Diabetes Care 36, no. 7: 1815-17. https://dx.doi. org $/ 10.2337 \% 2 F d c 12-2285$.

Armstrong, David G., J. Wrobel, and J. M. Robbins

2007 "Guest Editorial: Are Diabetes-Related Wounds and Amputations Worse than Cancer?” International Wound Journal 4, no. 4: 286-87. https://doi.org/10.1111/ j.1742-481X.2007.00392.x. 
Baldwin, James

1998 "Notes of a Native Son." In Collected Essays, edited by Toni Morrison, 5-136. New

Benton, Adia York: Library of America.

2015 HIV Exceptionalism: Development through Disease in Sierra Leone. Minneapolis: University of Minnesota Press.

Bertazzi, Pier Alberto, Dario Consonni, Silvia Bachetti, Maurizia Rubagotti, Andrea

Baccareli, Carlo Zocchetti, and Angela C. Pesatori

2001 "Health Effects of Dioxin Exposure: A 20-Year Mortality Study." American Journal of Epidemiology 153, no. 11: 1031-44. https://doi.org/10.1093/aje/153.11.1031.

Biehl, João

2007 Will to Live: AIDS Therapies and the Politics of Survival. Photographs by Torben Eskerod. Princeton, N.J.: Princeton University Press.

Biruk, Crystal

2018 Cooking Data: Culture and Politics in an African Research World. Durham, N.C.: Duke University Press.

Bowe, Benjamin, Yan Xie, Tingting Li, Yan Yan, Hong Xian, and Ziyad Al-Aly

2018 "The 2016 Global and National Burden of Diabetes Mellitus Attributable to PM2-5 Air Pollution." Lancet Planetary Health 2, no. 7: E301-E312. https://doi. org/10.1016/S2542-5196(18)30140-2.

Brandt, Allan M.

1997 "Behavior, Disease, and Health in the Twentieth-Century United States: The Moral Valance of Individual Risk." In Morality and Health: Interdisciplinary Perspectives, edited by Allan M. Brandt and Paul Rozin, 53-78. New York: Routledge.

Briggs, Charles L., and Clara Mantini-Briggs

2016 Tell Me Why My Children Died: Rabies, Indigenous Knowledge, and Communicative Justice. Durham, N.C.: Duke University Press.

Browne, Simone

2015 Dark Matters: On the Surveillance of Blackness. Durham, N.C.: Duke University Press.

Cohen, Lawrence

2018 Discussant for panel, "Communicability in Crisis: A Four-Field Dialogue." Panel organized by Elizabeth F. S. Roberts and Amy Moran-Thomas at the American Anthropological Association Annual Meeting, San Jose, Calif., November 14-18, 2018.

Colborn, Theo, Dianne Dumanoski, and John Peterson Myers

1997 Our Stolen Future: Are We Threatening Our Fertility, Intelligence, and Survival? A Scientific Detective Story. New York: Plume.

de-Graft Aikins, Ama

Forthcoming Sugar Disease, Bitter Medicine: Living with Diabetes in Ghana. London:

Durkheim, Émile Cambridge University Press and International African Library.

2001 The Elementary Forms of Religious Life. Translated by Carol Cosman. Oxford:

Farmer, Paul Oxford University Press. Originally published in 1912.

2001 Infections and Inequalities: The Modern Plagues. Berkeley: University of California Press.

Fassin, Didier

2011 Humanitarian Reason: A Moral History of the Present. Berkeley: University of California Press.

Fischer, Michael M. J.

2013 “The Peopling of Technologies." In When People Come First: Critical Studies in Global Health, edited by João Biehl and Adriana Petryna, 347-74. Princeton, N.J.: Princeton University Press. 
Fortun, Kim, and Mike Fortun

2005 "Scientific Imaginaries and Ethical Plateaus in Contemporary U.S. Toxicology." American Anthropologist 107, no. 1: 43-54. https://doi.org/10.1525/aa.2005.107. 1.043 .

Geary, James

2011 I Is an Other: The Secret Life of Metaphor and How It Shapes the Way We See the World. New York: HarperCollins.

Geronimus, Arline T., Margaret Hicken, Danya Keene, and John Bound

2006 "Weathering' and Age Patterns of Allostatic Load Scores among Blacks and Whites in the United States." American Journal of Public Health 96, no. 5: 826-33. https://dx.doi.org/10.2105\%2FAJPH.2004.060749.

Gough, Ethan, Englebert Emmanuel, Valerie Jenkins, Lorraine Thompson, Enrique Perez,

Alberto Barcelo, Robert B. Gerzoff, and Edward Gregg

2008 "Survey of Diabetes, Hypertension and Chronic Disease Risk Factors: Belize." Belize City, Belize: Pan American Health Organization.

Haagsma, J. A., N. Graetz, I. Bolliger, M. Naghavi, H. Higashi, E. C. Mullany, S. F. Abera et al.

2016 "The Global Burden of Injury: Incidence, Mortality, Disability-Adjusted Life Years and Time Trends from the Global Burden of Disease Study 2013." Injury Prevention 22, no. 1: 3-18. https://doi.org/10.1136/injuryprev-2015-041616.

Hatch, Anthony Ryan

2016 Blood Sugar: Racial Pharmacology and Food Justice in Black America. Minneapolis: University of Minnesota Press.

Hoover, Elizabeth

2017 The River Is in Us: Fighting Toxics in a Mohawk Community. Minneapolis: University of Minnesota Press.

IDF (International Diabetes Federation)

2017 IDF Diabetes Atlas. 8th ed. Brussels, Belgium: International Diabetes Federation. http://www.diabetesatlas.org/.

Jain, S. Lochlann

2013 Malignant: How Cancer Becomes Us. Berkeley: University of California Press.

Kenner, Alison

2018 Breathtaking: Asthma Care in a Time of Climate Change. Minneapolis: University of Minnesota Press.

Kistenberg, Robert S.

2005 "Amputation Prevention Strategies in Developing Nations: A Study of Belize." Master's thesis, University of Houston.

Krieger, Nancy

2011 Epidemiology and the People's Health: Theory and Context. Oxford: Oxford University Press.

Lamoreaux, Janelle

2016 "What If the Environment Is a Person? Lineages of Epigenetic Science in a Toxic China." Cultural Anthropology 31, no. 2: 188-214. https://doi.org/10.14506/ ca31.2.03.

Landecker, Hannah

2013 "Postindustrial Metabolism: Fat Knowledge." Public Culture 25, no. 3: 495-522. https://doi.org/10.1215/08992363-2144625.

Langston, Nancy

2010 Toxic Bodies: Hormone Disruptors and the Legacy of DES. New Haven, Conn.: Yale University Press.

Lilienfeld, David E.

2000 "John Snow: The First Hired Gun?" American Journal of Epidemiology 152, no. 1: 4-9. https://doi.org/10.1093/aje/152.1.4.

Livingston, Julie

2012 Improvising Medicine: An African Oncology Ward in an Emerging Cancer Epidemic. Durham, N.C.: Duke University Press. 
Lucas, B. G.

1967 "Hyperbaric Oxygen Therapy: Its History and Current Scope." Medical and Biological Illustration 17, no. 3: 174-80. https://www.ncbi.nlm.nih.gov/

Mauss, Marcel pubmed/5342666.

1966 The Gift: Forms and Functions of Exchange in Archaic Societies. Translated by Ian Cunnison. London: Cohen and West.

Mendenhall, Emily

2019 Rethinking Diabetes: Entanglements with Trauma, Poverty, and HIV. Ithaca, N.Y.: Cornell University Press.

Mendenhall, Emily, and Merrill Singer

2019 "The Global Syndemic of Obesity, Undernutrition, and Climate Change." The Lancet 393, no. 10173: 741. https://doi.org/10.1016/S0140-6736(19)30310-1.

Montoya, Michael J.

2011 Making the Mexican Diabetic: Race, Science, and the Genetics of Inequality. Berkeley: University of California Press.

Moran-Thomas, Amy

2010 “The Paradox of Non-Communicable Epidemic." West African Research Association News Spring: 8.

2019 Traveling with Sugar: Chronicles of a Global Epidemic. Oakland: University of California Press.

Murphy, Michelle

2017 "Alterlife and Decolonial Chemical Relations." Cultural Anthropology 32, no. 4: 494-503. https://doi.org/10.14506/ca32.4.02.

Nading, Alex M.

2017 "Local Biologies, Leaky Things, and the Chemical Infrastructure of Global Health." Medical Anthropology 36, no. 2: 141-56. https://doi.org/10.1080/0145974 0.2016 .1186672 .

Nash, Linda

2007 Inescapable Ecologies: A History of Environment, Disease, and Knowledge. Berkeley: University of California Press.

Neel, Brian A., and Robert M. Sargis

2011 "The Paradox of Progress: Environmental Disruption of Metabolism and the Diabetes Epidemic." Diabetes 60, no. 7: 1838-48. https://dx.doi.

Neil, M. J. E. org $/ 10.2337 \% 2$ Fdb $11-0153$.

2016 “Pain After Amputation.” British Journal of Anaesthesia Education 16, no. 3: 107-12.

Nelson, Alondra https://doi.org/10.1093/bjaed/mkv028.

2016 The Social Life of DNA: Race, Reparations, and Reconciliation after the Genome. Boston: Beacon Press.

Nerlich, Andreas G., Albert Zink, Ulrike Szeimies, and Hjalmar G. Hagedorn

2000 "Ancient Egyptian Prosthesis of the Big Toe." Lancet 356, no. 9248: 2176-79.

Nestle, Marion https://doi.org/10.1016/S0140-6736(00)03507-8.

2015 “Coca-Cola Says Its Drinks Don’t Cause Obesity: Science Says Otherwise." Guardian (UK), August 11.

Niewöhner, Jorg, and Margaret Lock

2018 "Situating Local Biologies: Anthropological Perspectives on Environment/Human Entanglement.” BioSocieties 2018, no. 13: 681. https://doi.org/10.1057/s41292017-0089-5.

Palacio, Joseph O., ed.

2005 The Garifuna, A Nation across Borders: Essays in Social Anthropology. Benque Viejo del Carmen, Belize: Cubola. 
Paradies, Y. C., M. J. Montoya, and S. M. Fullerton

2007 "Racialized Genetics and the Study of Complex Diseases: The Thrifty Genotype Revisited." Perspectives in Biology and Medicine 50, no. 2: 203-27.

Pecoraro, Roger, Gayle Reiber, and Ernest Burgess

1990 "Pathways to Diabetic Limb Amputation: Basis for Prevention." Diabetes Care 13, no. 5: 513-21.

Petryna, Adriana

2013 “The Origins of Extinction." Limn 3: 50-53. https://limn.it/articles/the-originsof-extinction/.

Porter, Roy

1999 The Greatest Benefit to Mankind: A Medical History of Humanity. New York: W. W. Norton.

Ralph, Laurence

2012 "What Wounds Enable: The Politics of Disability and Violence in Chicago." Disability Studies Quarterly 32, no. 3. http://dsq-sds.org/article/view/3270/3099.

Redfield, Peter

2013 Life in Crisis: The Ethical Journey of Doctors without Borders. Berkeley: University of California Press.

Roberts, Elizabeth F. S.

2017 "What Gets Inside: Violent Entanglements and Toxic Boundaries in Mexico City." Cultural Anthropology 32, no. 4: 592-619. https://doi.org/10.14506/ca32.4.07.

Rosenberg, Charles E.

1992 Explaining Epidemics: And Other Studies in the History of Medicine. Cambridge, UK: Cambridge University Press.

Sangaramoorthy, Thurka, and Adia Benton

2012 “Enumeration, Identity, and Health.” Medical Anthropology 31, no. 4: 287-91. https://doi.org/10.1080/01459740.2011.638684.

Seeberg, Jens, and Lotte Meinert

2015 "Can Epidemics Be Noncommunicable? Reflections on the Spread of 'Noncommunicable' Diseases.” Medicine Anthropology Theory 2: 54-71. https://doi. org/10.17157/mat.2.2.171.

Shapiro, Nicholas

2015 "Attuning to the Chemosphere: Domestic Formaldehyde, Bodily Reasoning, and the Chemical Sublime." Cultural Anthropology 30, no. 3: 368-93. https://doi.

Sharpe, Christina org/10.14506/ca30.3.02.

2016 In the Wake: On Blackness and Being. Durham, N.C.: Duke University Press.

Simmons, Kristen

2017 "Settler Atmospherics." Member Voices, Fieldsights, November 20. https://culanth.

Solomon, Harris org/fieldsights/settler-atmospherics.

2016 Metabolic Living: Food, Fat, and the Absorption of Illness in India. Durham, N.C.: Duke University Press.

Sontag, Susan

1988 Illness as Metaphor and AIDS and Its Metaphors. New York: Picador.

Street, Alice

2012 "Seen by the State: Bureaucracy, Visibility, and Governmentality in a Papua New Guinean Hospital.” Australian Journal of Anthropology 23, no. 1: 1-21. https://doi.

Sweeny, Robert W. org/10.1111/j.1757-6547.2012.00164.x.

2005 "Para-Sights: Multiplied Perspectives on Surveillance Research in Art Educational Spaces." Surveillance and Society 3, nos. 2-3: 240-50. https://doi.org/10.24908/ ss.v3i2/3.3504. 
Todd, Zoe

2017 "Fish, Kin and Hope: Tending to Water Violations in amiskwaciwâskahikan and Treaty Six Territory.” Afterall 43: 102-7. https://doi.org/10.1086/692559.

Velmurugan, Ganesan, Tharmarajan Ramprasath, Krishnan Swaminathan, Gilles Mithieux, Jeyaprakash Rajendhran, Mani Dhivakar, Ayothi Parthasarathy, et al.

2017 "Gut Microbial Degradation of Organophosphate Insecticides-Induces Glucose Intolerance via Gluconeogenesis." Genome Biology 18, no. 1: 8. https://doi.

Vogel, Sarah A. org/10.1186/s13059-016-1134-6.

2009 "The Politics of Plastics: The Making and Unmaking of Bisphenol A 'Safety." American Journal of Public Health 99, no. S3: S559-S566. https://dx.doi.

Wald, Priscilla org/10.2105\%2FAJPH.2008.159228.

2008 Contagious: Cultures, Carriers, and the Outbreak Narrative. Durham, N.C.: Duke University Press.

Walley, Christine J.

2013 Exit Zero: Family and Class in Postindustrial Chicago. Chicago: University of Chicago Press.

Weaver, Lesley Jo

2019 Sugar and Tension: Diabetes and Gender in Modern India. New Brunswick, N.J.: Rutgers University Press.

Whitmarsh, Ian

2013 “Troubling 'Environments': Postgenomics, Bajan Wheezing, and Lévi-Strauss." Medical Anthropology Quarterly 27, no. 4: 489-509. http://dx.doi.org/10.1111/ maq.12061.

Wilk, Richard

2006 Home Cooking in the Global Village: Caribbean Food from Buccaneers to Ecotourists. Oxford, UK: Berg.

Worboys, Michael

2007 "Was There a Bacteriological Revolution in Late Nineteenth-Century Medicine?" Studies in History and Philosophy of Science 38, no. 1: 20-42. https://doi. org/10.1016/j.shpsc.2006.12.003.

World Health Organization (WHO)

2009 “Age-Standardized DALYs per 100,000 by Cause and Member State." Geneva: WHO Department of Measurement and Health Information.

Wright, Uldine K.

2017 “Diabetic Foot: A Preliminary Study." Belize Journal of Medicine 6, no. 2: 24-27.

Yaghi, K., Y. Yaghi, A. A. McDonald, Gh. Yadegarfar, E. Cecil, J. Seidl, E. Dubois, S. Rawaf, and A. Majeed

2012 "Diabetes or War? Incidence of and Indications for Limb Amputation in Lebanon, 2007.” Eastern Mediterranean Health Journal 18, no. 12: 1178-86. https://apps.who. int/iris/handle/10665/118467.

Yates-Doerr, Emily

2015 The Weight of Obesity: Hunger and Global Health in Postwar Guatemala. Oakland: University of California Press. 